\title{
Effects of injection and ignition timing of a large direct injection spark ignition engine fuelled with a hydrogen-CNG mixture on its operating conditions and emissions
}

\author{
Michael Fenkl ${ }^{1, a}$ \\ ${ }^{1}$ Technical University of Liberec, Dept. of Power Eng. Equipment, Studentská 2, 46117 Liberec 1, Czech Rep.
}

\begin{abstract}
The effects of ignition and fuel injection timing of an experimental 2-liter single cylinder direct injection spark ignition gaseous fuel engine were examined experimentally in this study. An online-prepared mixture of $10-40 \%$ hydrogen with compressed natural gas was injected at 8 bar into the cylinder during the intake stroke at $1500 \mathrm{rpm}$. Heat release rates, maximum indicated pressures, cycle-to-cycle variability, and gaseous emissions were compared for different settings.
\end{abstract}

\section{Introduction}

The efforts to reduce the effects of exhaust emissions from internal combustion engines on environment and human health, and the resulting drive towards environmentally friendly power generation and transportation, motivate research groups and engine manufacturers to seek suitable alternative fuels, which can be produced from renewable resources, and which fulfill the increasingly demanding requirements for exhaust emissions. Such effort is not limited to vehicle engine, but also applies to stacionary engines used in distributed power generation in combined heat and power plants.

Compressed natural gas (CNG), composed of primarily methane, is a popular and widely used alternative fuel, which can be combusted with very low exhaust emissions compared to gasoline or diesel fuel [1]. Unlike automobile engines, which run at stoichiometric air-fuel ratio and use a three-way catalyst, larger power generation engines run lean, at an air-fuel ratio where the engine-out emissions of nitrogen oxides $\left(\mathrm{NO}_{\mathrm{x}}\right)$ are relatively low, while the combustion efficiency is still acceptable. Such approach allows for the use of biogas, which often contains impurities which are expensive to remove and which would poison a catalyst. Addition of even small percentage of hydrogen into the fuel was reported to substantially improve the fuel properties [15], especially the lean combustion limit, improving also the initial stages of combustion, $\mathrm{NO}_{\mathrm{x}}$ emissions and/or combustion efficiency.

Compared to gasoline and diesel fuel, methane already offers lower $\mathrm{CO} 2$ emissions. These are further decreased by displacement of methane with hydrogen. Extension of the lean combustion limit due to hydrogen

\footnotetext{
a Corresponding author: michael.fenkl@tul.cz
}

addition allows the engine to run leaner while maintaining comparable combustion quality [1], allowing to reduce combustion temperatures which have a strong effect on NOx. A possible downside of hydrogen addition is lower volumetric energy density of hydrogen relative to methane and liquid fuels, resulting in displacement of combustion air with fuel.

$\mathrm{Ma}$ [3] reports that on a naturally aspirated 6.2-liter, six-cylinder engine, addition of $20 \%$ hydrogen by volume improved both the mean indicated pressure variability and the maximum indicated pressure, while the emissions of hydrocarbons (HC) were decreased but NOx slightly increased. Huang [4] reports that addition of hydrogen to CNG allows for a significant increase in exhaust gas recirculation (EGR) rate while maintaining low indicated pressure variability. Thurnheer [5] reports that addition of $15 \%$ hydrogen by volume has allowed, compared to methane only, to delay ignition timing by 4.5 crank angle degrees (CAD).

\section{Experimental setup}

\subsection{Engine and instrumentation}

The experiments were carried on a unique singlecylinder research engine, made from a 12-liter, sixcylinder LIAZ ML 636 diesel engine. The cylinder no. 6 was equipped with a modified piston, lowering the compression ratio to $12: 1$. The cylinder head was fitted with a fuel injector (used in place of a glow plug), with a spark plug (used in place of a diesel injector) with an ignition module, and with a cylinder pressure sensor. The remaining five cylinders were used to pump air into a reservoir feeding the working cylinder, simulating 
turbocharging. The parameters of the engine are given in Table 1. All engine modifications were done in-house and were described in [6-8]. Hardware and software for controlling the fuel injection and ignition was fabricated in-house. The schematics and photo of the engine is given in Fig. 1. The photo of the fuel injector is given in Fig. 2.

The engine was coupled to a DC electric dynamometer, allowing for both motoring and braking of the engine. The engine was operated at $1500 \mathrm{rpm}$, a nominal speed of engines used in medium-size combined heat and power plants. The engine was not equipped with throttle; the power output was regulated by changing the air-fuel ratio.

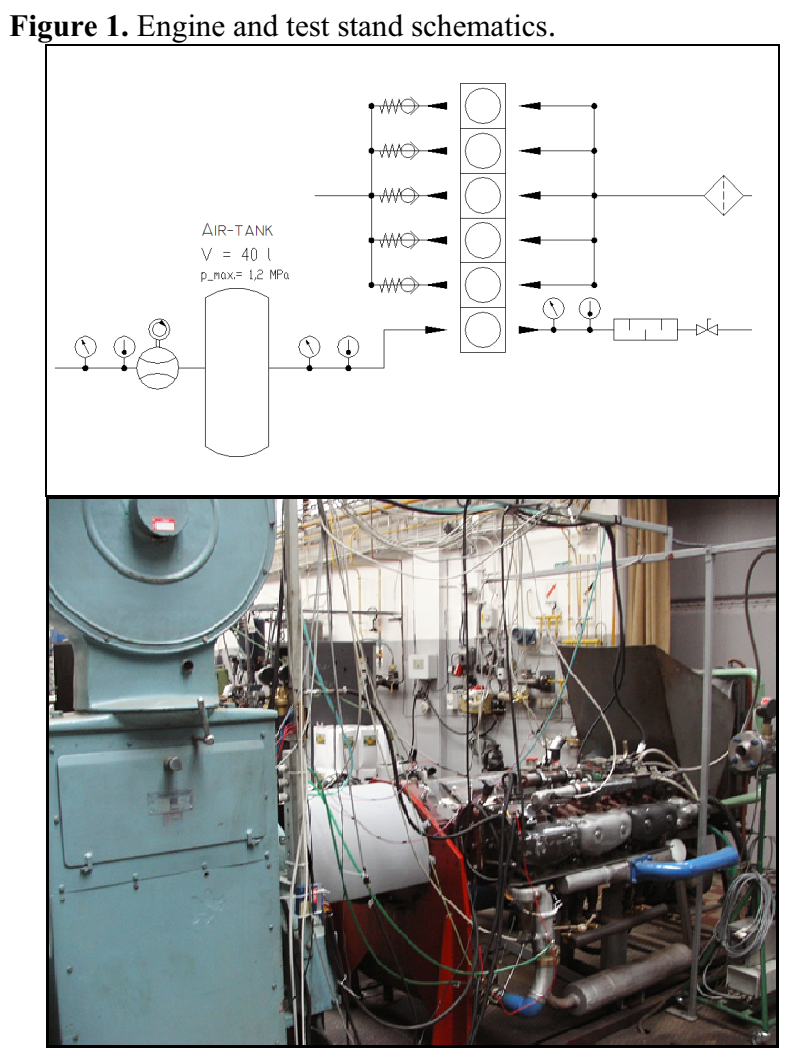

Figure 2: Fuel injector

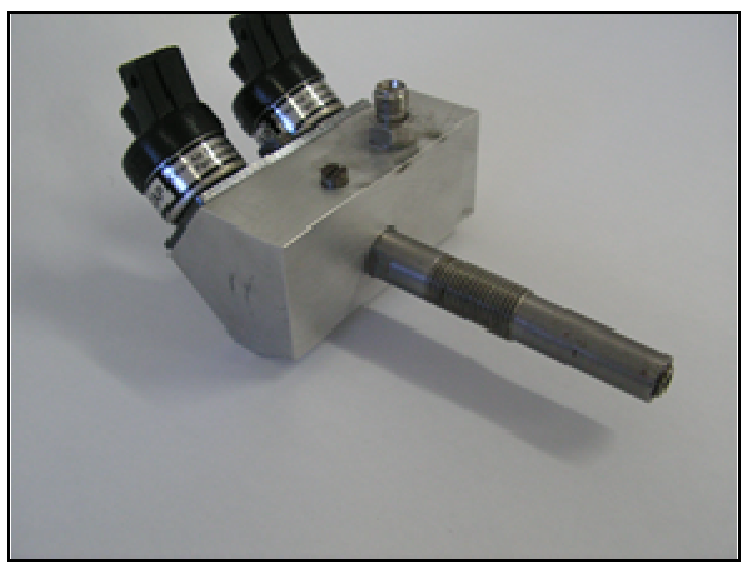

Table 1. Engine specifications.

\begin{tabular}{|c|c|}
\hline Type of engine & naturally aspirated SI engine \\
\hline Number of cylinders (-) & 1 \\
\hline Displacement volume (L) & 1,99 \\
\hline Compression ratio (-) & 12 \\
\hline Bore (mm) & 130 \\
\hline Stroke (mm) & 150 \\
\hline Connecting rod length (mm) & \\
\hline Intake valve timing & 250 \\
\hline Exhaust valve timing & IVO: $3^{\circ}$ BTDC $44^{\circ}$ ABDC \\
\hline
\end{tabular}

The in-cylinder pressure was measured by a piezoelectric indicated pressure sensor (GU 21D, AVL), connected to a base unit (Indimetr 619, AVL), and analyzed by Concerto software (AVL). Other engine parameters were measured at 1 -second intervals with a data acquisition system (cDAQ-9172, with modules NI 9217, NI 9211, NI 9202, NI 9205, National Instruments) and processed by an in-house written software using the LabView application (National Instruments).

The methane content of the fuel was measured by an NDIR analyzer, developed, calibrated and validated in earlier work by this group [9]. The concentrations of HC, $\mathrm{CO}, \mathrm{NOx}$ and $\mathrm{CO} 2$ in the exhaust were measured by an in-house developed portable emissions monitoring system [Vojtíšek SAE 2009-24-0148].

\subsection{Fuel mixture preparation}

Hydrogen and CNG fuels were taken from the highpressure laboratory fuel supply system. Natural gas was taken from the distribution network, compressed by a fueling station compressor and stored in CNG tanks. Bottled compressed hydrogen was purchased (Linde Gas) and stored on site. Both gases were passed through Coriolis-type fuel consumption meters (Micro Motion Elite CMF 010) a pressure regulators set to $2.5 \mathrm{MPa}$ feeding an in-house developed mixing device, allowing online mixing of the fuels with on-the-fly adjustment of the mixture composition. The device is desrcibed in Czech patent no. 298642 [10], and shown in Fig. 3. The resulting fuel mixture was analyzed using an in-house NDIR analyzer [9]. The fuel supply system schematics is presented in Fig. 4. 
Figure 3. Fuel mixing device.

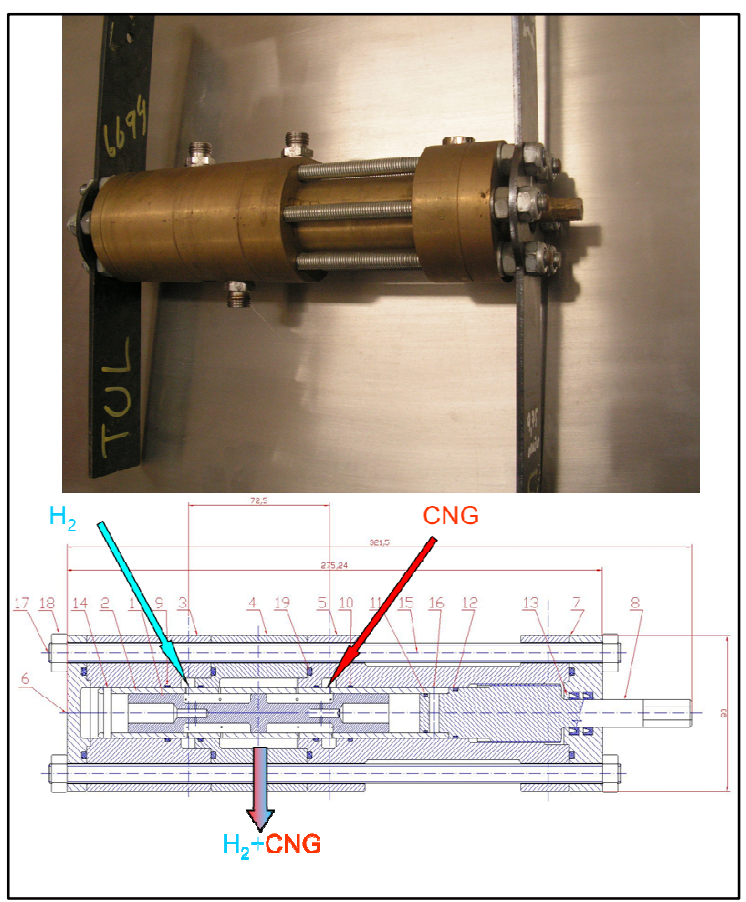

Figure 4. Fuel supply system.

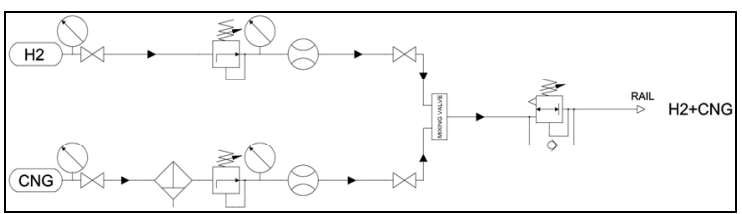

\section{Results and discussion}

Throughout this section, unless indicated otherwise, the fuel injection timing took place during the intake stroke and is measured in degrees after the top dead center (ATDC), while the ignition timing (during the compression stroke) is measured in degrees before the top dead center (BTDC).

\subsection{Ignition timing effects}

Out of the relatively large set of aggregate data, operating points with comparable excess air ratio of 1.33 , comparable fuel composition of $13-14 \% \quad \mathrm{H} 2$, and comparable injection timing at 50 ATDC (40 ATDC for ignition timing 24 BTDC).

It is apparent from Fig. 5 that as the ignition timing is advanced, the concentrations of NOx increase, while $\mathrm{HC}$ and $\mathrm{CO}$ decrease, and $\mathrm{CO} 2$ remains constant. (The small deviation in the fuel composition can be considered insigificant according to [3].) These results are in agreement with another study [3]. The relative changes to 22 BTDC are given in Fig. 6.
Figure 5. Effects of ignition timing on exhaust gas composition.

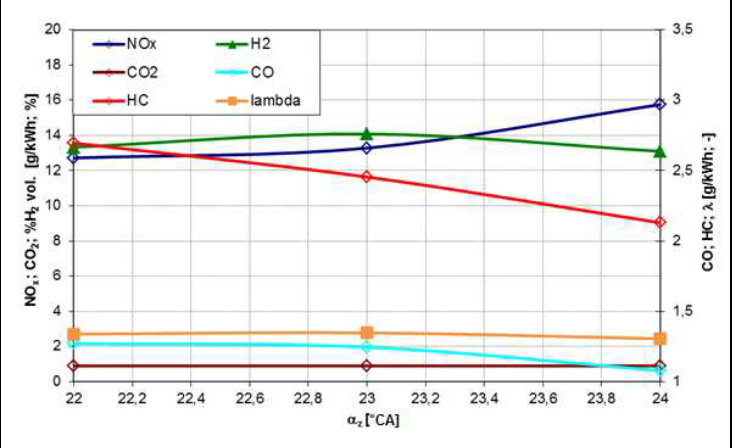

Figure 6. Relative changes in concentrations of $\mathrm{NOx}, \mathrm{CO} 2, \mathrm{CO}$, $\mathrm{HC}$ as a function of ignition timing.

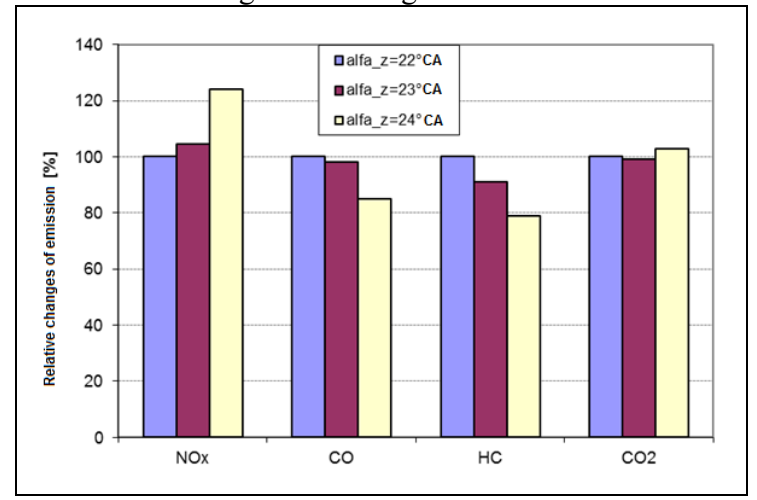

Also, as the ignition timing is advanced, the duration of the main phase of the combustion (defined as the period from $10 \%$ to $90 \%$ of heat released) is longer, as shown in Fig. 7. This allows for improved combustion efficiency and decrease in $\mathrm{HC}$ and $\mathrm{CO}$ emissions. Detailed examination of the heat release progress, shown in Fig. 8, suggests that this change is attributed nearly entirely to the second phase of combustion (50-90\% heat released), while the first phase of combustion $(10-50 \%$ heat released), and also the sum of ignition delay and the initial phase of combustion (from nominal ignition angle to $10 \%$ heat released) are comparable across all ignition timings examined.

Figure 7. Crank angle at which $10 \% ; 50 \%$ and $90 \%$ of the energy in the fuel is released, and the length of the intervals 10$50 \%, 50-90 \%$ and $10-90 \%$, as a function of ignition timing.

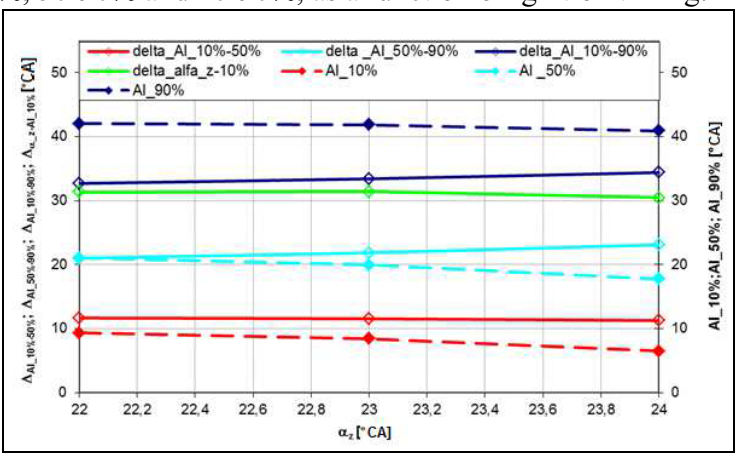


Figure 8. Heat release rates as a function of ignition timing.

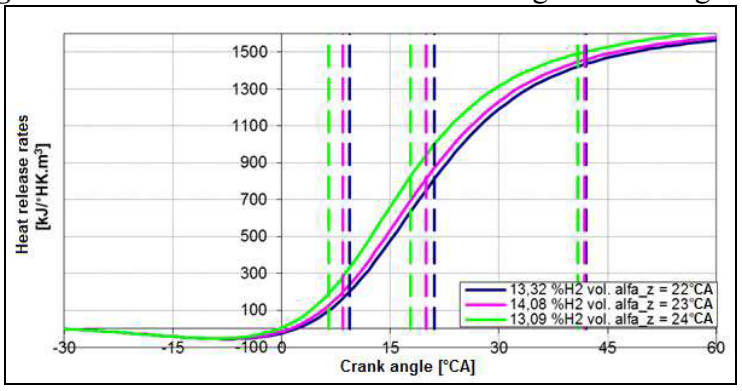

From these data it can be ascertained that the onset of the oxidation reactions is not majorly influenced by the ignition timing and that the ignition timing influences primarily the second phase of the combustion.

\subsection{Effects of start of the injection timing}

Three groups of data, each of which composed of points with comparable air-fuel ratio, hydrogen content of fuel, and ignition timing, have been examined.

In the first group, fuel containing $31 \%$ of hydrogen by volume was injected at 35-40 ATDC, the ignition timing was 27 BTDC, and the excess air ratio was 1.68.

The second group spans injection timing 50-80 ATDC, excess air ratio of $1.58,34.6 \%$ hydrogen by volume, and ignition at 27 BTDC.

In the third group, the fuel was injected at 100-120 ATDC, contained $30.7 \%$ hydrogen by volume, excess air ratio was 1.48 , and ignition timing 27 BTDC.

Figure 9. Concentrations of $\mathrm{NO}_{\mathrm{x}}, \mathrm{CO}_{2}, \mathrm{CO}, \mathrm{HC}$ as a function of injection timing.

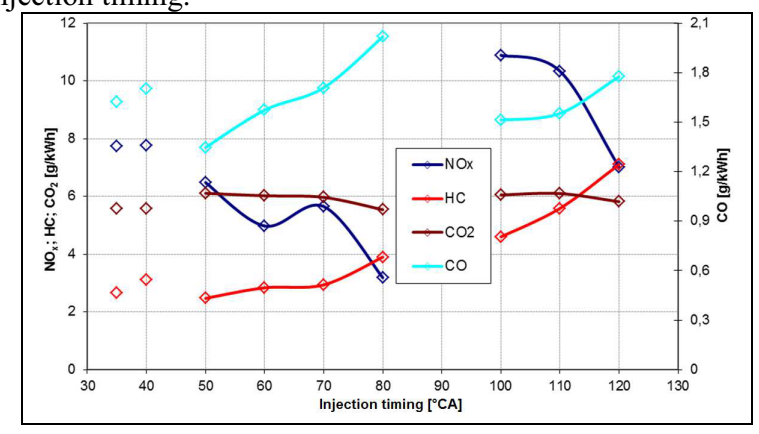

For the second group, data in Fig. 9 suggest that with advancement of the start of the fuel injection, $\mathrm{HC}$ and $\mathrm{CO}$ decrease considerably, NOx increases, and there is very little increase in $\mathrm{CO} 2$. This is in agreement with [11], in which it has also been found that around 120 ATDC the NOx trend reverses and NOx moderately increase with further delayment of the start of the injection up to the bottom dead center, after which NOx dramatically decreases.

The step change from 80 to 100 ATDC is attributed to differences in air-fuel ratio and hydrogen concentration, as shown in Fig. 10.
Figure 10. Effect of start of the injection on maximum and mean indicated pressure.

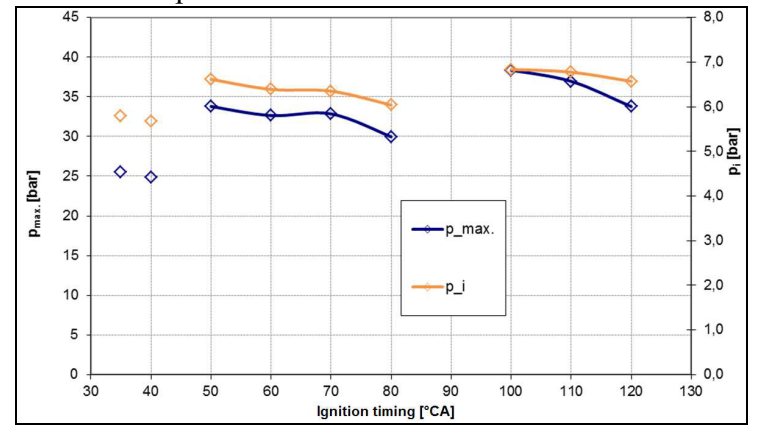

Later injection decreases the time available for mixing of the fuel with the air, reducing the mixture homogenity, with a resulting increase in $\mathrm{HC}$ and $\mathrm{CO}$. This is in agreement with the observed increse in variability of the mean indicated pressure, plotted in Fig. 11. This claim is also supported by the shift of the combustion onset, which, with delayment of the injection, is shifting away from the ignition (increased ignition delay), as apparent in Fig. 12. Delaying the start of injection is therefore believed to result in the degradation of the homogenity of the mixture. While such change may be insignificant compared to comparable effects on liquid fuels, it is well observable, as demonstrated in measurable changes in parameters indicating onset and quality of the combustion. The effect on mixture homogenity is also discussed in [11].

Figure 11. Effect of start of the injection on variability in maximum and mean indicated pressures.

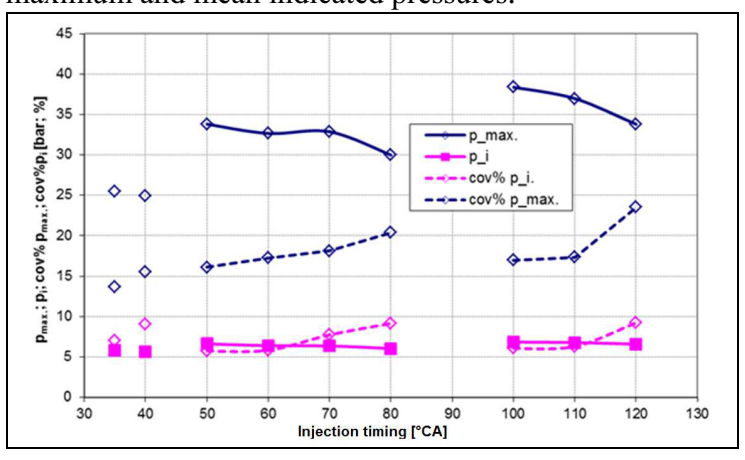

Figure 12. Crank angle at which $10 \% ; 50 \%$ and $90 \%$ of the energy in the fuel is released, and the length of the intervals 10 $50 \%, 50-90 \%$ and $10-90 \%$, as a function of timing of the start of the fuel injection.

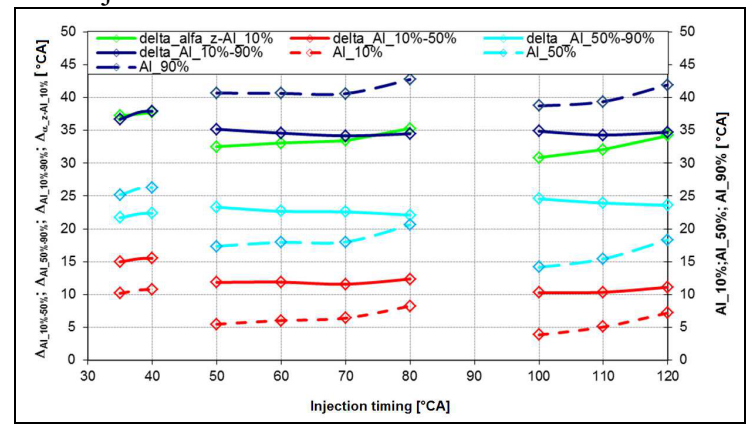




\section{Conclusions}

- With the advancing ignition timing, while keeping the air-fuel ratio and fuel injection timing constant, the emissions of NOx increased, $\mathrm{HC}$ and $\mathrm{CO}$ decreased, and $\mathrm{CO} 2$ did not change significantly. There was no detectable change in the onset of combustion, its early stage, and its main stage until 50\% heat released; time from $50 \%$ to $90 \%$ heat released increased with advanced ignition timing. The comparable timing of the first half of the combustion suggests that the ignition timing has little effect on pre-combustion and early combustion reactions. The longer duration of the second half of the combustion is believed to have resulted in more complete combustion and observed reductions in $\mathrm{HC}$ and $\mathrm{CO}$ emissions.

- Delayment of the start of the fuel injection, while ignition timing and air-fuel ratio are kept constant, has resulted in lower NOx and higher $\mathrm{HC}$ and $\mathrm{CO}$ emissions, while $\mathrm{CO} 2$ concentrations were comparable.

- Characteristic points of heat release rate are significantly delayed with increasing injection delay in each area with the constant ignition timing; air-fuel ratio and $\mathrm{H} 2 / \mathrm{CNG}$ were significant. The initialization time $\left({ }^{\circ} \mathrm{CA}\right)$ between ignition timing and $\mathrm{Al} \_10 \%$ is significant depended on start of injection while the time between Al_10\% and Al_50\% is approximately constant and the time between Al_50\% and Al_90\% decreases.

\section{References}

1. G.A. Karim, I. Wierzba, Y. AlAlousi, Methanehydrogenmixtures as fuels, J Hydrogen Energy . (1996)

2. M. Fanhua, W. Yu, Study on the extension of lean operation limit through hydrogen enrichment in a natural gas spark-ignition engine, International journal of hydrogen energy, vol. 33, p. 1416-1424, (2008)

3. M. Fanhua, W. Yu, L. Haiquan, L. Yong, W. Junjun, D. Shangfen, Effects of hydrogen addition on cycleby-cycle variations in a lean burn natural gas sparkignition engine, International journal of hydrogen energy vol. 33, p. 823-831, (2008)

4. H. Erjiang, H. Zuohua, L. Bing, Z. Jiajun, G. Xiaolei, Experimental study on combustion characteristics of a spark-ignition engine fueled with natural gashydrogen blends combining with EGR, International journal of hydrogen energy, vol. 34, p. 1035-1044 (2009)

5. T. Thurnheer, P. Soltic, S.I. engine fuelled with gasoline, methane and methane/ hydrogen blends: Heat release and loss analysis, International journal of hydrogen energy, vol. 34, p. 2494-2503, (2009)

6. C. Scholz, Koncepce jednoválcových motorů pro výzkum, XXXVIII. medzinárodná vedecká konferencia pracovníkov katedier a pracovísk spal'ovacích motorov vysokých škôl na Slovensku a v Čechách. Bratislava, (2007)

7. C. Scholz, M. Fenkl, Pístový spalovací motor na vodík, Mezinárodní konference RT\&E (2006)
8. M. Svoboda, M. Fenkl, Moving electrode spark plug experiments, XLI. International scientific conference of czech and slovak university departments and institutions dealing with research of combustion engines KOKA 2010, (2010)

9. M. Vojtíšek, M. Fenkl, Analysis of gaseous fuel blends and mixtures using inexpesive "garage-grade" gas analyzers., Journal of KONES Powertran and Transport 15. (2008)

10. V. Dvořák, Směšovací ventil, Patentový spis 298642 , (2007)

11. C. Bleechmore, S. Brewster, Hydrogen Addition Strategy for Lean Limit Extension of a Natural Gas Engine, ANGVA 2007, (2007) 